\title{
Good Governance and Internal Control on the Prevention of Fraud in the Procurement of Goods and Services for Government Agencies
}

\author{
Evada Dewata ${ }^{1, *}$ Elfira Hidayanti Farah ${ }^{2}$ Hadi Jauhari $^{1}$ Yuliana Sari $^{1}$ \\ ${ }^{1}$ Politeknik Negeri Sriwijaya, Palembang, Indonesia \\ ${ }^{2}$ Alumni of the Public Sector Accounting Study Program Politeknik Negeri Sriwijaya \\ *Corresponding author. Email: evada78@polsri.ac.id
}

\begin{abstract}
This study aims to empirically prove the effect of good governance and internal control on the prevention of fraud in the procurement of state-owned goods and services in the regional government of South Sumatra Province. The research population was in 37 Regional Apparatus Organizations (OPD), the sampling technique used purposive sampling and obtained as many as 128 respondents. This type of research data is primary data using a questionnaire. The analysis technique uses multiple linear regression models and it is found that partially, there is a positive and significant effect of good governance and internal control on the prevention of fraud in the procurement of goods and services. The results of the study have implications for local governments to continue improving the application of good governance principles strictly and continuously run the internal control system to minimize legitimacy and prevent fraud in the process of procuring goods and services.
\end{abstract}

Keywords: Good Governance; Internal Control; Fraud; Fraud Triangle Theory

\section{INTRODUCTION}

Local governments are required to carry out the process of procurement of state-owned goods and services with good governance [1] and the implementation of the procurement of state-owned goods and services must refer to the Regulation of the National Procurement Board (LKPP) of the Republic of Indonesia Number 12 of 2021 [2] regarding Guidelines for the Implementation of Government Procurement of Goods/Services. However, what has happened is that there are still many findings of fraudulent cases of procurement of goods and services, as revealed by the Deputy Chairman of the Corruption Eradication Commission (KPK) that 70 percent of corruption cases handled by the KPK occurred in the procurement of goods and services [3]. Data from the Corruption Eradication Commission (KPK) shows that cases of procurement of goods and services are the most common types of corruption cases and the data shows a significant increase in corruption cases in the procurement of goods and services. Since 2014-2020, it has continued to increase and harm state finances, from 2014 as many as 15 cases, continuing to increase until 2020 as many as 27 cases of fraud [4] as shown in Figure 1 below.

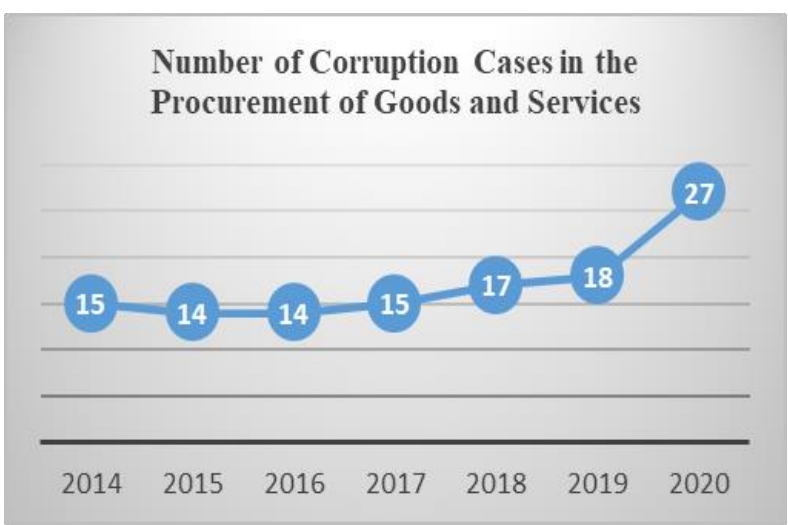

Figure 1 Number of Corruption Cases in the Procurement of Goodss and Services

Source: www.kpk.go.id, 2021

This study tries to highlight the external factors of preventing fraud in the procurement of state-owned goods and services by analyzing the implementation of good governance and internal control in the Regional Government of South Sumatra Province. As we already know, the good governance movement in Indonesia has been implemented since the reform era until now, but its implementation is still not optimal. There are still many frauds, including in the process of procuring goods and 
services. $[5,6]$ revealed that the process of procurement of goods and services cannot be separated from the implementation of all the principles of good governance and good governance has a positive effect on fraud prevention because it can eliminate the factors driving fraud [7].

The Association of Certified Fraud Examiners (ACFE) divides fraud into three groups, namely financial statement fraud, asset misappropriation, and corruption [7], and the efforts to minimize fraud are commitments that must be seriously carried out by local governments because the opportunity to commit fraud to exist in all lines of the organization where internal control is weak $[9,10]$. In the procurement process itself, it is necessary to have internal control as revealed [10, $11,12,13]$ that effective internal control can prevent fraud. Although several research results are showing that internal control does not affect fraud prevention because internal control has not been carried out as much as possible by the local government $[14,15]$.

Based on this phenomenon, this study was conducted to reveal whether there is an effect of Good Governance and Internal Control on the Prevention of Fraud in the Procurement of Goods and Services. Referring to the results of previous studies which reveal more about this problem in the private sector, to fill the gap this research was carried out in the government sector, especially in local governments. The urgency of this research is to provide information for local governments to accelerate budget absorption and reduce opportunities for corruption in local governments. The purpose of this study is to provide empirical evidence of the effect of good governance and internal control on the prevention of fraud in the procurement of goods and services.

\section{LITERATURE REVIEW}

The Fraud Triangle Theory describes three causes of fraud, namely perceived pressure, perceived/opportunity, and rationalization [16]. Fraud is a deliberate act by individuals or groups within the management, staff, or third parties by committing fraud or manipulation to obtain illegal profits $[17,18]$. The principle of Good Governance is expected to be able to prevent fraud [7]. Procurement of goods/services fraud occurs if there is a deviation in the process of procurement of goods/services because it ignores the principles and ethics that have been set by the Regulation of the National Procurement Board (LKPP) of the Republic of Indonesia Number 12 of 2021 [2]. Theory Fraud Triangle also explained that if internal controls are weak, it can be an opportunity to conduct fraud. Effective internal control can provide a guarantee that there will be no fraud [19], and so that internal control can function properly, it must evaluate all applicable systems and procedures [20] and so that the effectiveness of internal control runs well, the monitoring, information and communication processes, risk assessment, and control environment must be ensured to be well-coordinated [21]. Good internal control automatically detects and allocates errors so that fraud does not occur.

\section{RESEARCH METHOD}

This research was conducted at the Regional Government of South Sumatra Province, Indonesia, namely the Regional Apparatus Organization of South Sumatra Province consisting of agencies/bureaus, offices, and units. The study was conducted in MarchJuly 2021. The total population of the study was 37 Regional Apparatus Organizations (OPD), consisting of 26 Offices, 9 Bureaus/Agencies, and 2 Other Work Units that procured goods/services. The sampling technique used purposive sampling with the criteria 1) Regional apparatus organizations have implemented an electronic system in the implementation of the procurement of goods and services, 2) Respondents in this study were employees in the procurement sector, namely Budget Users, Budget Users, Commitment Maker Officials, and other Procurement Sections. Respondents taken were 20 people in the Bureau of Procurement of Goods and Services and 3 people in each other OPD so that the research sample was 128 respondents. This type of research data is primary data, sources were obtained from the answers to the questionnaires distributed to the respondents. The research variables consist of a dependent variable that the Prevention of Fraud Procurement of Goods/Services $(\mathrm{Y})$ and the independent variables namely good governance (X1) and Internal Control (X2) using a Likert scale.

Table 1. The Results of Validity and Reliability Test

\begin{tabular}{|lcccl|}
\hline \multicolumn{1}{|c}{ Variable } & $\begin{array}{c}\text { N of } \\
\text { items }\end{array}$ & Coef & $\begin{array}{c}\text { Cronbach's } \\
\text { Alpha }\end{array}$ & Information \\
\hline Good & 25 & $0.398-$ & 0.956 & Valid and \\
Governance(GG) & & 0.873 & & Reliable \\
Internal Control & 25 & $0.600-$ & 0.977 & Valid and \\
(IC) & & 0.941 & & Reliable \\
Prevention of & 27 & $0.451-$ & 0.967 & Valid and \\
Fraud & & 0.886 & & Reliable \\
Procurement of & & & & \\
Goods and & & & & \\
Services (PF) & & & \\
\hline
\end{tabular}

Source: Data Processing, 2021

Table 1 is the result of the validity and reliability test of the questionnaire. The analysis stage starts from testing the data quality (validity test and reliability test) where the instrument test results are declared valid if $r$ count $>r$ table, the value of $r$ table is known to be 0.306 
at a significance level of $5 \%, \mathrm{n}=30(\mathrm{df}=\mathrm{n}-2)$. The reliability test can be declared reliable if the Cronbach Alpha value is $>0.60$ [22].

The hypotheses tested are as follows:

H1: Good Governance has a positive and significant effect on the prevention of fraud in the procurement of goods and services.

$\mathrm{H} 2$ : Internal control has a positive and significant effect on the prevention of fraud in the procurement of goods and services.

The analysis technique used multiple linear regression with the application named SPSS version 19.00 .

Table 2. Frequency of Respondents' Answers

\section{RESULTS AND DISCUSSIONS}

From the results of the questionnaires distributed to 128 respondents, only $120(93.75 \%)$ respondents returned the questionnaires and the data could be processed. The results of the data statistics (Table 2) show the average value obtained based on respondents' answers to each variable indicator and it can be found that almost all independent variables and have dimensions that are considered fair. There is only one measurement dimension that is categorized as good, namely Monitoring on the Internal Control variable.

\begin{tabular}{|c|c|c|c|c|c|}
\hline No & Variable & Dimension & $\begin{array}{l}\text { Question } \\
\text { Number } \\
\end{array}$ & $\begin{array}{l}\text { Average } \\
\text { Score } \\
\end{array}$ & Criteria \\
\hline \multirow[t]{6}{*}{1} & \multirow[t]{5}{*}{ Good Governance } & Transparency & $1-5$ & 2.760 & Fair \\
\hline & & Accountability & $6-10$ & 2.866 & Fair \\
\hline & & Responsibility & $11-15$ & 2.898 & Fair \\
\hline & & Independency & $16-20$ & 3.098 & Fair \\
\hline & & Fairness and Equality & $21-25$ & 2.871 & Fair \\
\hline & \multicolumn{3}{|c|}{ Good Governance Variable Average } & 2.998 & Fair \\
\hline \multirow[t]{6}{*}{2} & \multirow[t]{5}{*}{ Internal Control } & Control Environment & $1-5$ & 3.266 & Fair \\
\hline & & Risk Assessment & $6-10$ & 3.088 & Fair \\
\hline & & Control Activities & $11-15$ & 3.267 & Fair \\
\hline & & Information and Communication & $16-20$ & 3.241 & Fair \\
\hline & & Monitoring & $21-25$ & 3.476 & Good \\
\hline & \multicolumn{3}{|c|}{ Average of Internal Control Variables } & 3.286 & Fair \\
\hline \multirow[t]{7}{*}{3} & \multirow{6}{*}{$\begin{array}{l}\text { Prevention of Procurement } \\
\text { of Goods and Services Fraud }\end{array}$} & Strengthening the Legal Framework & $1-5$ & 2.948 & Fair \\
\hline & & Transparent Procedure & $6-10$ & 2.976 & Fair \\
\hline & & Opening a Tender Document & $11-13$ & 3.093 & Fair \\
\hline & & Offer Evaluation & 14-18 & 3.270 & Fair \\
\hline & & Delegation of Authority & $19-23$ & 3.033 & Fair \\
\hline & & Independent Examination and Audit & $24-27$ & 3.225 & Fair \\
\hline & \multicolumn{3}{|c|}{$\begin{array}{l}\text { Average of the Variables of Prevention of Procurement of Goods and Services } \\
\text { Fraud }\end{array}$} & 3.086 & Fair \\
\hline
\end{tabular}

Source: Data Processing, 2021

Description: Interval 1.00-1.080 = Very Bad; $1.80-2.60=$ Bad; $2.60-3.40=$ Fair; $3.40-4.20=$ Good; $4.20-5.00=$ Very Good.

The results of multiple linear regression testing can be seen in Table 3.

Table 3. Multiple Linear Regression Test Results

\begin{tabular}{|c|c|c|c|c|}
\hline \multirow[b]{2}{*}{ Model } & \multicolumn{3}{|c|}{ Dependent Variable ${ }^{\mathrm{a}}$} & \multirow[b]{2}{*}{ Conclusion } \\
\hline & $\begin{array}{c}\text { Coefficient } \\
(\beta)\end{array}$ & $\mathrm{t}$ & $\begin{array}{c}\text { Sig (2- } \\
\text { tail) }\end{array}$ & \\
\hline (Constant) & 0.791 & 4.090 & 0.000 & - \\
\hline GG & 0.210 & 2.970 & 0.004 & $\begin{array}{c}\mathrm{H}_{1} \\
\text { accepted }\end{array}$ \\
\hline IC & 0.653 & 11.074 & 0.000 & $\begin{array}{c}\mathrm{H}_{2} \\
\text { accepted }\end{array}$ \\
\hline \multicolumn{5}{|l|}{ Adjusted $\mathrm{R}^{2}$} \\
\hline F count & \multicolumn{2}{|c|}{93.402} & $.000^{\mathrm{b}}$ & Significant \\
\hline
\end{tabular}

a. Dependent Variable: PF

b. Predictors: (Constant), GG, IC
The Effect of Good Governance on the Prevention of Fraud in the Procurement of Goods and Services

The results of Hypothesis 1 testing indicate that good governance has a positive and significant effect on the prevention of fraud in the procurement of goods and services. It is concluded that $\mathrm{H} 1$ is accepted based on the results of multiple linear regression tests (table 3 ). $t$ count is 2,970 and it is greater than the t table value of 1,981 and the probability value is less than 0.05 , which is 0.004 . These findings prove that the better the implementation of the principles of Good Governance, the more accurate it is in preventing fraud in the procurement of goods and services. The results support the theory Fraud Triangle Theory that says fraud may occur when being in a situation with high pressure, a chance and offenders have low integrity, then with the strict implementation of good governance, will limit the need or opportunity to commit fraud. The results of this 
study can be supported by the findings of the highest answer frequency value of respondents (table 2), namely the independence dimension of 3,098 which means it is considered quite good, and overall it can be seen that the implementation of the principles of good governance in the regional government of South Sumatra Province, Indonesia is fair.

The results of the study support the findings $[5,6,7]$ that good governance has a positive effect on the prevention of fraud in the procurement of goods and services, meaning that the better the implementation of good governance is to ensure that the process of procurement of goods and services is running according to regulations. The results of this study have implications for the Regional Government to continue to be committed and consistently apply the principles of good governance in every activity of procurement of goods and services and make it a government culture so that opportunities for fraud can be avoided.

\section{The Effect of Internal Control on the Prevention of Fraud in the Procurement of Goods and Services}

The test results show that internal control has a positive and significant effect on the prevention of fraud in the procurement of goods and services. It means that $\mathrm{H} 2$ is accepted based on the results of multiple linear regression tests (table 3 ) $\mathrm{t}$ count for the audit fee variable is 11,074 and is greater than the t table value of 1,981 and the probability value is 0.000 which means it is smaller than 0.05 . This finding shows that the more effective the implementation of internal control, the more effective it is to prevent fraud in the procurement of goods and services in the regional government of South Sumatra Province, Indonesia. This finding is supported by the results of the frequency table of respondents' answers (table 2) where the highest frequency of answers lies in the Monitoring dimension, which is 3,476 (good), meaning that if the monitoring process is carried out early on, it can ensure that the policies set by the leadership have been implemented properly and if there is an error can be quickly identified and corrected. The results of this study also support the Fraud Triangle Theory, which states that internal control is an effective way to prevent fraud, as evidenced by the results of this study, it can be seen that the monitoring process and control activities can minimize and limit fraudulent practices.

The results of this study are in line with [10, 13], that the implementation of effective controls can assist local governments in preventing fraud. However, contrary to research $[14,15]$, that internal control does not affect fraud prevention. The results of this study have implications for the Regional Government to design and implement an effective internal control system starting from a conducive control environment, continuous risk assessment, control, and monitoring activities carried out in an organized manner according to organizational culture and communication between organizational lines.

\section{CONCLUSION}

The results of this study prove empirically that partially, good governance and internal control have a positive and significant effect on preventing fraud in the procurement of state-owned goods and services. The results of this study have implications especially for local governments that fraud in the procurement of goods and services can be prevented by increasing external factors, namely the application of good governance principles strictly and evaluating and carrying out internal controls on an ongoing basis.

For further research, it is possible to add new variables, namely internal factors of the possibility of fraud such as level of education, integrity, selfawareness, and opportunity.

\section{ACKNOWLEDGMENTS}

Thank you to Polytechnic State of Sriwijaya for supporting and facilitating the Overseas Collaborative Research team by providing PNBP Research grants for 2021.

\section{REFERENCES}

[1] Sopian, A. (2012). Government Goods/Services Procurement Strategy. LKPP \& Jakarta

[2] Republik Indonesia. (2021). Peraturan Presiden Nomor 12 Tahun 2021 Tentang Pengadaan Barang/Jasa Pemerintah.

[3] https://nasional.kompas.com/read/2020/08/26/14404 821/kpk-sebut-70-persen-kasus-korupsi-terkaitpengadaan-barang-dan-jasa. Diakses pada tanggal 4 April 2021

[4] https://www.kpk.go.id/id/statistik/penindakan/tpkberdasarkan-jenis-perkara. Diakses pada tanggal 4 April 2021.

[5] Dewata, E., Ardiani, S., Sandrayati, S., \& Afsari, M. M. (2017). Pengaruh Penerapan Good Corporate Governance Terhadap Kinerja Pengadaan Barang dan Jasa Secara Elektronik (EProcurement) Pada BUMN Di PT Semen Baturaja (Persero) Tbk Palembang. Jurnal Akuntansi, Ekonomi Dan Manajemen Bisnis, 5(2), 228-241.

[6] Shaleha, Q. I., \& Shaleha, S. M. (2021). The Implementation of Good Corporate Governance (GCG) Principles Over Goods \& Services Procurement Over PT. Angkasa Pura Solusi. Journal of Multidisciplinary Academic, 5(3), 222-229.

[7] Soleman, R. (2013). Pengaruh pengendalian internal dan good corporate governance terhadap pen cegahan fraud. Jurnal Akuntansi dan Auditing Indonesia, 17(1), 57-74.

[8] Albrecht, W. S., Albrecht, C. O., Albrecht, C. C., \& Zimbelman, M. F. 2011. Fraud Examination. 4th ed. Mason: South-Western.dict 
[9] Dewi, K. Y. K., \& Ratnadi, N. M. D. (2017). The Effect of Internal Control and Integrity on the Tendency of Accounting Fraud in the Regional Work Units of Denpasar City. E-Journal of Accounting, 2017 (1), 917-941.

[10] Marciano, B., Syam, A., \& Ahmar, N. (2021). Penerapan Pengendalian Internal Terhadap Kecurangan: Sebuah Literatur Review. WACANA EKONOMI (Jurnal Ekonomi, Bisnis dan Akuntansi), 20(2), 130-137.

[11] Sari, R., Su'un, M., \& Nurwanah, A. (2021). Effect of internal control, whistleblowing role and data asymmetry against fraud prevention. Point of View Research Accounting and Auditing, 2(1), 92-99.

[12] Herawaty, N., \& Hernando, R. (2021). Analysis of Internal Control of Good Corporate Governance and Fraud Prevention (Study at the Regional Government of Jambi City). Sriwijaya International Journal of Dynamic Economics and Business, 4(2), 103-118

[13] Primastiwi, A., Wardani, D. K., \& Hanisah. (2020). Pengaruh Penerapan Eprocurement dan Sistem Pengendalian Internal Pemerintah Terhadap Pencegahan Kecurangan Pengadaan Barang. JSEH (Jurnal Sosial Ekonomi dan Humaniora), 6(1), 3036.

[14] Ali, M., FarhanahAyop, N., Ghani, E. K., \& Hasnan, S. (2020). The Effect of Employees' Perceptions on Internal Control System Mechanisms Towards Employee Fraud Prevention. Journal of Critical Reviews, 7(18), 972-986.

[15] Kamaliah, K., Marjuni, N. S., Mohamed, N., Mohd-Sanusi, Z., \& Anugerah, R. (2018). Effectiveness of monitoring mechanisms and mitigation of fraud incidents in the public sector.
Administration and Public Management Review, (30)

[16] Istiyanto, A. S., \& Yuyetta, E. N. A. (2021). Analisis Determinan Financial Statement Fraud dengan Pendekatan Fraud Diamond (Studi Empiris pada Perusahaan Sektor Manufaktur yang Terdaftar di BEI pada Tahun 20162018). Diponegoro Journal of Accounting, 10(1).

[17] Tuanakotta, M. T. (2013). Audit berbasis ISA (International Standards on Auditing). Salemba Empat

[18] Tjahjono, S., Untung, B., Tarigan. J., Effendi, JAP., And Hardjanti., Y. (2013). Business Crimes and Ethics: Concepts and Case Studies of Fraud in Indonesia and Global, Jakarta: Andi Offset

[19] Mahendra, K. Y., Dewi, A. E. T., \& Rini, G. A. I. S. (2021). Pengaruh Audit Internal dan Efektivitas Pengendalian Internal Terhadap Pencegahan Kecurangan (Fraud) Pada Bank Bumn di Denpasar. Jurnal Riset Akuntansi Warmadewa, 2(1), 1-4.

[20] Sujana, I. K., Suardikha, I. M. S., \& Laksmi, P. S. P. (2020). Whistleblowing System, Competence, Morality, and Internal Control System Against Fraud Prevention on Village Financial Management in Denpasar. E-Jurnal Akuntansi, 30(11), 2780 . https://doi.org/10.24843/eja.2020.v30.i11.p06

[21] Agustina, G. P., \& Riharjo, I. B. (2016). FaktorFaktor Yang Mempengaruhi Kelemahan Pengendalian Intern Pemerintah Daerah. Jurnal Ilmu Dan Riset Akuntansi, 5(April), 1-15.

[22] Ghozali, I. (2018). Aplikasi Analisis Multivariate Dengan Program IBM SPSS 25 (Edisi 9). Badan Penerrbit Universitas Diponegoro 